\title{
Biodegradable Plastic from Cassava and Organic Acid as a Synthetic Plastic Replacement
}

\author{
Aji Ridho Pangestu a,1,*, Raifa Tryas Shara ${ }^{\text {b,2, Zahrul Mufrodi }}$ b,3 \\ ${ }^{a}$ Departemen Teknik Kimia, Fakultas Teknik, Universitas Gadjah Mada, Jalan Grafika No.2 Kampus UGM, Yogyakarta, 55281 \\ ${ }^{\mathrm{b}}$ Program Studi Teknik Kimia, Fakultas Teknologi Industri, Universitas Ahmad Dahlan, Jalan Ringroad Selatan, Tamanan, Banguntapan, Bantul, \\ Yogyakarta, 55166 \\ ${ }^{1}$ ajiridhopangestu1@mail.ugm.ac.id*; ${ }^{2}$ raifatshara@gmail.com; ${ }^{3}$ zahrul.mufrodi@che.uad.ac.id \\ * corresponding author
}

ARTICLE INFO

Article history

Received July 25, 2019

Revised September 30, 2019

Accepted September 30, 2019

Keywords

cassava

organic acid

sorbitol

chitosan

biodegradable plastic

\section{ABSTRACT}

Currently, plastic has been widely used for various purposes of packaging food and beverages. The use of synthetic plastic is increasingly then become a waste that cannot be degraded and pollute the environment. In Southeast Asia generates 379.198 million tons of plastic waste per year, meanwhile, Indonesia became the first contributor to the largest plastic waste producer which is 187.2 million tons per year. Biodegradable plastic can be an alternative to eco-friendly and easily degraded packaging materials as one way to replaced synthetic plastic. Cassava flour could utilize to make biodegradable plastic with cassava starch content reach $81.6 \%$. The addition of a sorbitol plasticizer is as a giver of elastic properties to the material and chitosan as an amplifier and antimicrobial. The variation of weight ratio in gram that used is organic acids 50(1), 60(2), and 70(3). The variations of sorbitol are 3(A), 6(B), and $9(\mathrm{C})$. The variations of chitosan are 1(i), 3(ii), and 5(iii). The organic acids used are apple vinegar and rice vinegar with $2 \%$ acetic acid as a comparison. The research procedure begins with making cassava starch, making a film of biodegradable plastic, and sample testing. The film of biodegradable plastic has performed by tensile strength test analysis, elongation at break test, and biodegradable test. The results showed that the highest percent biodegradable is on $2 \mathrm{Ci}$ with the results is $64.58 \%$. The best of mechanical properties reached by using apple vinegar with the results of tensile strength is $105.98 \mathrm{~kg} / \mathrm{cm}^{2}$ and elongation at break is $129.91 \%$.

\section{Introduction}

Nowadays polymer utilization has become an integral part of human life, for example, synthetic plastics. Domestic plastic consumption until the end of the year has projected to grow by $5.4 \%$ to reach 5.6 million tons [1]. The use of synthetic plastics is increasingly becoming an irreversible waste and polluting the environment. The used of waste plastic does not destroy even though it has been stockpiled for a long time. Resulting in a buildup of plastic waste has causes pollution and environmental damage. Depend on Indonesian's statistic waste data, the production of plastic waste in Indonesia about 187.2 billion tons per year. This amount has estimated will be increasing along with the needs and demands [2].

Biodegradable plastic is an alternative eco-friendly packaging material because it made from renewable materials and scientifically readily degraded by microorganisms or weather. The abundant renewable material in Indonesia is cassava, which is, has a high potential as a raw material of biodegradable plastics. Making plastic biodegradable from natural materials that could be degraded by microorganisms and as an alternative to environmentally friendly packaging materials. The benefit 
that could be obtained from this research is to make biodegradable plastic as an alternative food packaging material that is safe for health. Then we can know the best variation of material composition. Indonesia is an agricultural country with major livelihoods from agriculture and plantation sectors. One of the agricultural commodities produced in Indonesia is cassava. According to the Badan Pusat Statistik (BPS), in 2015 Indonesia was produced more than 21.8 million tons of cassava per year [3]. Indonesia is one of the largest cassavas producing countries in the world after Nigeria and Thailand. Chemical compositions of cassava starch are as follows $13 \%$ of water content, $0.2 \%$ of ash, $0.8 \%$ of fat, $1 \%$ of protein, $3.4 \%$ of fiber, and $81.6 \%$ of starch [4].

Starch is composed of two main polymers such as amylose and amylopectin, starch also contains protein $0.25 \%$ and fat $0.1 \%-0.3 \%$ [5]. Biodegradable plastics based on starch could be degraded by pseudomonas bacteria and bacillus breaks the polymer chain into its monomers. Burned biodegradable plastic does not produce harmful chemical compounds [6]. Making biodegradable plastic processes should be added plasticizer so the resulting plastic more elastic, flexible, and resistant to water [7]. One of the most widely used plastic in making biodegradable plastic is sorbitol. This addition aims to improve physical properties, mechanical properties and protects the plastic from a microorganism that can damage it. Then, we need to add chitosan as anti-microbial and reinforcing agents. The chitosan used as an additive in bioplastic manufacturers will reduce water adsorption rate, improve mechanical properties, and reduce humidity film properties [8].

Plastics are biodegradable with starch-based materials using the gelatinization process. Gelatinization is a gel-forming event that begins with the hydration of starch, which is the process of absorption of water molecules by starch molecules. If the suspension of starch granules in water is heated to a temperature of $60-70{ }^{\circ} \mathrm{C}$ gradually large starch granules balloon rapidly [9]. The starchy starch forms a crystalline structure. The starch has dissolved in $2 \%$ acetic acid and then heated to a certain temperature to evaporate the water content and leave the film layer stiff and stable. Acetic acid was used to hydrolyze amylose and acid atmosphere giver.

Based on research from Sitompul, et al [10] got the result that the best treatment was found on the use of plasticizer sorbitol with concentration of $3 \%$ with water contains value is $11.86 \% ; 0.12$ $\mathrm{mm}$ thick; film solubility $62.35 \%$; tensile strength $2.83 \mathrm{~N} / \mathrm{cm}^{2}$; and percent elongation of $44.65 \%$. The mechanical properties of polymer type LDPE (Low-Density Polyethylene) is a tensile strength of $10 \mathrm{MPa}$ and a breakup extension of $400 \%$ [11]. In this study using organic acid for the gelatinization process with $2 \%$ acetic acid as a comparison. Sorbitol has used as a giver of elastic properties in plastic films. The materials used in the form of organic materials to be safer for health and the environment. Mechanical properties of plastic according to SNI (Standar Nasional Indonesia/ National Standard Indonesia) are as follows. The standard for tensile strength is 24.6-302 MPa, elongation at break is $21-220 \%$, and hydrophobicity is $99 \%$ [6].

\section{Research Methodology}

\subsection{Instruments}

Knives, digital scales, blenders, gauze, plastic containers, ovens, measuring cups, glass stirrers, thermometers, hot plates, beaker glasses, volume pipettes, pro pipettes, dropper pipes, watch glasses, molds $20 \mathrm{~cm}$ x $15 \mathrm{~cm}$.

\subsection{Materials}

Distilled water, chitosan, cassava starch, sorbitol, apple vinegar, rice vinegar, $2 \%$ acetic acid, $95 \%$ alcohol. The variable used in the research is shown in Table 1. 
Table 1. Variable used in the research units in weight/volume ratio

\begin{tabular}{lccc}
\hline \multicolumn{1}{c}{ Variable } & \multicolumn{3}{c}{ Variable (label) / value } \\
\hline \multirow{2}{*}{ Acetic Acid } & $(1)$ & $(2)$ & $(3)$ \\
\cline { 2 - 4 } Sorbitol & $50 \mathrm{ml}$ & $60 \mathrm{ml}$ & $70 \mathrm{ml}$ \\
\cline { 2 - 4 } & $(\mathrm{A})$ & $(\mathrm{B})$ & $(\mathrm{C})$ \\
\hline \multirow{2}{*}{ Chitosan } & $3 \mathrm{ml}$ & $6 \mathrm{ml}$ & $9 \mathrm{ml}$ \\
\cline { 2 - 4 } & $(\mathrm{i})$ & $(\mathrm{ii})$ & $(\mathrm{iii})$ \\
\hline
\end{tabular}

\subsection{Making Cassava Starch}

The washing cassava and water have smoothed using a blender with a ratio of cassava and water $1 \mathrm{~kg}$ : $0.5 \mathrm{~L}$ water. Extract until obtained the dregs and filtrate. Then extract it again and deposited both of the filtrates for 2 hours to get cassava starch deposition. Then separated deposited from water and drying in the oven at $70{ }^{\circ} \mathrm{C}$ for 24 hours. Finely grind the dry starch and screening until it passes a 140-200 mesh sieve.

\subsection{Making biodegradable plastic's film}

- Variable: acetic acid 2\%

1) 10 grams of cassava starch dissolved in $2 \%$ acetic acid (labels $1,2,3$ ) with stirring bar at $65-70{ }^{\circ} \mathrm{C}$ and gelatinization time about $20-25$ minutes.

2) $1 \mathrm{gr}$ of chitosan dissolved in $100 \mathrm{ml}$ of acetic acid with stirring for 30 minutes at $65{ }^{\circ} \mathrm{C}$. Prepared for 3 times for different acetic acid label.

3) Cassava starch solution mixed with chitosan solution with stirring for 15 minutes until homogenous. Then, added 3 gr of sorbitol, stirred, and heated for 15 minutes until homogenous at $65^{\circ} \mathrm{C}$.

4) Cooled at room temperature for 5 minutes to avoid bubbles in plastic film.

5) The mold is cleaned using $95 \%$ alcohol and pours the film plastic solution into the mold. Dried for 24 hours at room temperature.

6) Remove the plastic film from the mold.

7) Test tensile strength and elongation at break for each label (labels 1,2,3) of 2\% acetic acid. The best result has fixed for the next step.

- Variable: sorbitol

Do the steps as a variable of acetic acid, but for the first step used the best acetic acid result labeling (1/2/3). Then on third steps, used sorbitol in the variable (labels A, B, C). Finally, test tensile strength and elongation at break for each label (labels A, B, C) of sorbitol. The best result has fixed for the next step.

- Variable: chitosan

Do the steps as a variable of acetic acid, but using the fixed value from previous steps. Labels $1 / 2 / 3$ for the first step and labels $\mathrm{A} / \mathrm{B} / \mathrm{C}$ for the third step. Then, used chitosan in the variable (labels $\mathrm{i}$, ii, iii) on the second step.

Then the best results serve as a fixed variable used for apple vinegar and rice vinegar as a comparison.

\subsection{Analysis of plastic's film}

Tensile strength and elongation at break used ASTM D 638 -14 test method. Only four best samples had tested with this method. For other samples had tested in Chemical Engineering Laboratory of Universitas Ahmad Dahlan. The test was conducted at Testing and Calibration Laboratory, Center for Leather Rubber and Plastics of Yogyakarta.

The biodegradable test has performed for five best samples. The test steps are sample planted in moist soil in 3-5 cm depth and left for seven days with daily observation. Before planting, measured the area of the tested sample and kept the soil is moist every day. The observation was made by 
estimating the surface area of biodegradable plastic film. The formula of percent biodegradable has shown in equation (1) as below.

$$
\% \text { biodegradable }=\frac{A_{1}-A_{2}}{A_{1}} \times 100 \%
$$

Where

$$
\begin{array}{ll}
A_{1}= & \text { surface area of the sample before being tested } \\
A_{2}= & \text { surface area of the sample after being tested }
\end{array}
$$

\section{Results and Discussion}

The research methodology scheme with the determination of the best treatment of each variable has described in the following scheme:

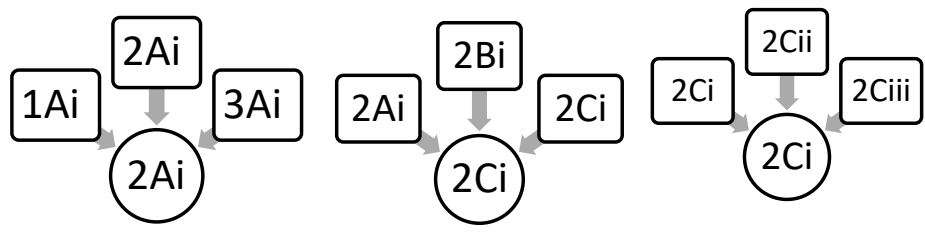

Fig. 1. The best treatment of each variable

Each sample on various variables was analyzed by tensile strength and elongation at the break test's method so obtained the best sample results with the variation of $2 \mathrm{Ai}$ and $2 \mathrm{Ci}$ as shown in Fig 1 above. The mean of variable code is $1 / 2 / 3=$ variation of acetic acid, $\mathrm{A} / \mathrm{B} / \mathrm{C}=$ variation of sorbitol, and $\mathrm{i} / \mathrm{ii} / \mathrm{iii}=$ variation of chitosan that as shown as in Table 1 .

\subsection{The Results of Biodegradable Testing}

The relationship between $\%$ biodegradable with biodegradable time up to seven days for the best five samples can be presented in Fig. 2.

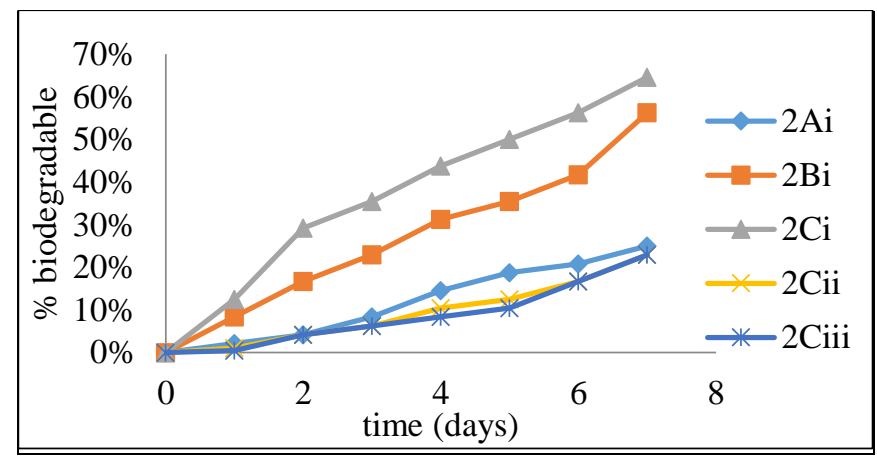

Fig. 2. Correlation between $\%$ biodegradable and time to degraded in the best five of plastic film

Based on Fig. 2. we can conclude that the highest biodegradable percentage is in the sample with $2 \mathrm{Ci}$ treatment that is equal to $64.58 \%$. Then followed by a sample with $2 \mathrm{Bi}$ treatment with a value equal to $56.25 \%$. The ratio of sorbitol weight between the $2 \mathrm{Ci}$ and $2 \mathrm{Bi}$ treatments is $6: 4$. This proves that the more sorbitol used will speed up the biodegradation process of the plastic film.

Linearly the smallest biodegradable percentage has found in the 2Ciii sample, which was $22.92 \%$ and 2Cii sample, which was under 30\%. Comparison of chitosan weight between 2Ci treatments with 2Cii and 2Ciii is 1:3:5. This proves that more chitosan is used it will slow the biodegradation process of plastic film. This is because chitosan as an additive in the manufacture of biodegradable plastic will reduce the speed of water absorption. It impacts the biodegradation time is more slowly for more chitosan used.

The addition of plasticizer can increase the flexibility and permeability of water vapor, gas. Therefore, with the increasing volume of sorbitol, the plastic film easier to degrade. Chitosan was used as an additive in bioplastic will reduce the rate of water absorption, improve tensile strength, and reduce the moisture of the film. Therefore, with the increasing mass of chitosan, the plastic film is 
harder to degrade. Thus, we conclude that the sample with the fastest degradation time is in the largest plasticizer volume and the smartest chitosan mass.

\subsection{The Results of Tensile Strength and Elongation at Break Testing}

The result of tensile strength and elongation at break for many variables has shown in Table 2. As bellow.

Table 2. The result of a tensile strength test and the breaking elongation at $2 \%$ acetic acid usage for four best plastic film with ASTM D 638 - 14 test method.

\begin{tabular}{ccc}
\hline \multirow{2}{*}{ Label } & \multicolumn{2}{c}{ PARAMETER } \\
\cline { 2 - 3 } & Tensile strength (MPa) & Elongation at break (\%) \\
\hline 2Bi (1) & 10.7922 & 15 \\
\hline 2Bi (2) & 12.6672 & 10 \\
\hline 2Bi (3) & 11.6385 & 15 \\
\hline Label & & PARAMETER \\
\hline Average & Tensile strength (MPa) & Elongation at break (\%) \\
\hline 2Ci (1) & 11.6993 & 13.33 \\
\hline 2Ci (2) & 9.5262 & 65 \\
\hline 2Ci (3) & 10.4892 & 75 \\
\hline Average & 10.9746 & 71.67 \\
\hline 2Cii (1) & 10.3303 & 45 \\
\hline 2Cii (2) & 3.9746 & 55 \\
\hline 2Cii (3) & 4.2757 & 45 \\
\hline Average & 3.1754 & 48.33 \\
\hline 2Ciii (1) & 3.8089 & 15 \\
\hline 2Ciii (2 & 6.6165 & 25 \\
\hline 2Ciii (3) & 7.3353 & 30 \\
\hline Average & 6.7744 & 23.33 \\
\hline & 6.9088 & \\
\hline & & \\
\hline & & \\
\hline & & \\
\hline
\end{tabular}

Based on table 2. we can conclude that the best tensile strength is on plastic film labeled with $2 \mathrm{Bi}$ (11.6993 MPa) then followed with $2 \mathrm{Ci}(10.3303 \mathrm{MPa})$. The best elongation at break is on plastic film labeled with $2 \mathrm{Ci}(71.67 \%)$ then followed by $2 \mathrm{Cii}(48.33 \%)$. Overall, the best sample is on plastic film labeled $2 \mathrm{Ci}$ that with the treatment $60 \mathrm{~mL}$ of acetic acid, $6 \mathrm{~mL}$ of sorbitol, and $1 \mathrm{gr}$ of chitosan.

The factors that influence the result of bioplastic assays are acetic acid, sorbitol, chitosan, and drying technique. The use of a low concentration of acetic acid makes the product safer for the environment. Sorbitol has used as a plasticizer caused by stability and non-toxicity. The addition of plasticizer can increase the flexibility and permeability of water vapor, gas, and improve film resistance especially if stored at low temperatures. Chitosan was used as an amplifier, so it can increase tensile strength and elongation at break. The more chitosan has used so the plastic biodegradable will be stronger but no more elastic.

Overall the best sample was $2 \mathrm{Ci}$ with a tensile strength value of $105.34 \mathrm{~kg} / \mathrm{cm}^{2}(10.33 \mathrm{MPa})$ and a breakup of $71.67 \%$. The $2 \mathrm{Ci}$ sample has defined as a fixed variable for apple vinegar and rice vinegar. Then the samples were tested tensile strength and elongation broke up at Chemical Engineering 
Laboratory, Universitas Ahmad Dahlan. Comparison of tensile strength test results and breaking elongation for the best treatment $2 \mathrm{Ci}$ on the use of $2 \%$ acetic acid, apple vinegar, and rice vinegar had presented in table 3 .

Table 3. Comparison of tensile strength test results and breaking elongation on the use of $2 \%$ acetic acid, apple vinegar, and rice vinegar for best plastic film treatment (2Ci)

\begin{tabular}{ccc}
\hline Parameter & Variable & Results \\
\hline Tensile Strength, $\mathbf{k g} / \mathbf{c m}^{\mathbf{2}}$ & Acetic acid 2\% & 105,34 \\
& Apple vinegar & 105,98 \\
& Rice vinegar & 93,09 \\
\hline Elongation at break, \% & Acetic acid 2\% & 71,67 \\
& Apple vinegar & 129,91 \\
& Rice vinegar & 144,67 \\
\hline
\end{tabular}

Based on table 3, we can conclude that the highest tensile strength value is in apple vinegar usage with a value of $105.98 \mathrm{~kg} / \mathrm{cm}^{2}$. While the value of the largest breakup is found on the use of rice vinegar is worth $144.67 \mathrm{~kg} / \mathrm{cm}^{2}$. Based on the test results we can conclude that apple vinegar and rice vinegar can replace the function of $2 \%$ acetic acid with mechanical properties that are not much different. The use of organic acids of apple vinegar has a value of $105.98 \mathrm{~kg} / \mathrm{cm}^{2}$ or $10.393 \mathrm{MPa}$. This tensile strength value has passed the standard of LDPE plastic but has not passed the SNI. While the value of elongation of breaks on apple vinegar has a value of $129.91 \%$ which has passed the mechanical properties of plastic in accordance with SNI.

\subsection{The Results of Organoleptic Analysis}

Texture and color for the plastic film with $2 \%$ acetic acid variables, apple vinegar, and rice vinegar see in figure 3.

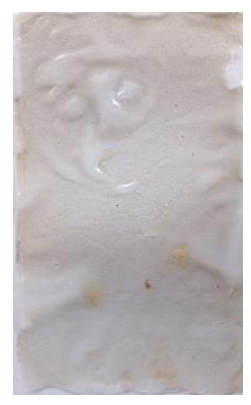

(a)

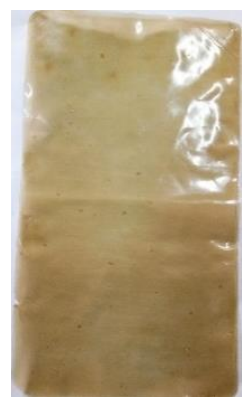

(b)

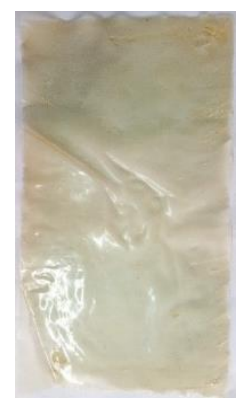

(c)

Figure 3. Differences in texture and color of plastic films: (a) $2 \%$ acetic acid variables (b) variables apple cider (c) variable rice vinegar

In texture and color between plastic films that use $2 \%$ acetic acid, apple vinegar, and rice vinegar quite different. Apple vinegar has a brownish color; on the $2 \%$ acetic acid variable has a white color of silence, while the rice vinegar variable has a brownish white color. The plastic film has a smooth texture and not sticky.

\section{Conclusion}

The plastic film could be made from cassava starch material. Apple vinegar and rice vinegar can replace $2 \%$ acetic acid in the gelatinizing process. In the use of $2 \%$ acetic acid has the highest value of tensile strength at $2 \mathrm{Bi}$ treatment that is about $119.30 \mathrm{~kg} / \mathrm{cm}^{2}$, the highest breaking extension on the $2 \mathrm{Ci}$ treatment of $71.67 \%$, and the fastest biodegradable percentage for seven days at $2 \mathrm{Ci}$ treatment which is $64.58 \%$. Determination of $2 \mathrm{Ci}$ treatment as the best mixture of ingredients. In general, the best mechanical properties on apple vinegar use than the use of rice vinegar and acetic acid $2 \%$ with the value of tensile strength of $105.98 \mathrm{~kg} / \mathrm{cm}^{2}(10,393 \mathrm{MPa})$ and the value of elongation at break is 
$129.91 \%$. The value is close to the value of SNI for plastics in general and passes the standard tensile strength of LDPE plastic with a value of $101.972 \mathrm{~kg} / \mathrm{cm}^{2}$. Plastic film on the use of apple vinegar has a brownish color while on the use of $2 \%$ acetic acid has a white color of silence, while the use of rice vinegar has a brownish white color. The use of apple vinegar and rice vinegar on the manufacture of biodegradable plastic are environmentally friendly, safe for health, and could be degraded perfectly.

\section{Acknowledgment}

Thanks to Dr. Zahrul Mufrodi, S.T., M.T. from Chemical Engineering Department, Universitas Ahmad Dahlan who has guided us to carry out this research.

\section{References}

[1] Rini, Annisa Sulistyo, 2017. "Konsumsi Plastik di Dalam Negeri Naik 5,4\%." BISNIS: December, $17^{\text {th }}$, 2017.

[2] Putri, Gloria Setyvani. "Laut Dunia Darurat Sampah Plastik, Indonesia Turut Menyumbang." Kompas, December, $15^{\text {th }}, 2017$.

[3] Badan Pusat Statistik. 2015. "Produksi Ubi Kayu Menurut Provinsi (Ton), 1993-2015." Badan Pusat Statistik.

[4] Subagio, A. 2007. "Industrialisasi Modified Cassava Flour (MOCAL)." Jember: Fakultas Teknologi Pertanian Universitas Jember.

[5] Asgargon, A.O. and Akintayo E.T. 2012. Morphological, Functional and Pasting Properties of Starches Separated Cultivars Rice Grown in Nigeria. International Food Research Journal. Vol 19, No.2, pg. 665671.

[6] Anggraini, F. 2013. "Aplikasi Plasticizer Gliserol pada Pembuatan Plastik Biodegradable dari Biji Nangka." Semarang: Chemistry Department, Faculty of MIPA UNNES.

[7] Darni, Y. Chici, A. \& Ismiyati, S. 2008. "Sintesa Plastik Biodegradable dari Pati Singkong dan Gelatin dengan Plasticizer Gliserol.” Seminar Nasional Sains dan Teknologi II. Universitas Lampung.

[8] Selpiana, Jeo Fitra Riansya \& Kevin Yordan. 2015. "Pembuatan Plastik Biodegradable dari Tepung Nasi Aking." Chemical Engineering Department, FT UNSRI.

[9] Harsono, Suparlan \& S. Triwahyuni. 2006. Desain dan Uji Kinerja Mesin Pemisah Lembaga Biji Jagung (Determinator) Sistem Basah. Jurnal Engineering Pertanian. Vol 4 No.1, April 2006.

[10] Sitompul, et.all, 2017. Pengaruh Jenis dan Konsentrasi Plasticizer Terhadap Sifat Fisik Edible Film Kolang Kaling (Arenga pinnata). Malang: Jurnal pangan dan agroindustri. Vol 5, No. 1: 13-25, January 2017.

[11] Crompton, T.T. 2012. "Physical Testing of Plastics." United Kingdom: Smithers Rapra Technology Ltd. 